\title{
FOLLOWERS' PERSONALITY AND INDIGENOUS LEADERSHIP: PERCEIVED ASTABRATA LEADERSHIP STYLE IN INDONESIAN HIGHER EDUCATION
}

\author{
Ninik Setiyowati ${ }^{a, b^{*}}$, Ahmad Zabidi Bin Abdul Razak ${ }^{a}$ \\ ${ }^{a}$ Faculty of Education, University Malaya \\ ${ }^{b}$ Fakultas Pendidikan Psikologi, Universitas Negeri Malang \\ "Corresponding author email: Ninik.setiyowati.fppsi@um.ac.id
}

\begin{abstract}
This study is aimed to investigate how followership personality is related to the leadership perception in the context of higher education. Regarding this study, the researcher selected 20 lecturers spread in several universities in Indonesia. The participants were selected based on the criteria required. The selected participants then filled the Big Five Personality Inventory (BFI) which had been translated and adjusted in Indonesian language and culture to categorize the leader in some types of characteristics. Next, they were interviewed to describe their supervisor on Indonesian indigenous leadership by modifying astabrata question list. This research used a qualitative method whose result was analyzed using the deductive thematic analysis in order to classify followers' perception. The results of this study showed the correlation between followers' level of the five traits and perceptions of Astabrata leadership. Followers with a high score of neuroticisms were associated with Perceptions of Matahari (sun) and angin (wind) leadership style. Besides, Followers with conscientiousness traits described their leader as having Langit (sky) and Bintang (stars) leadership style. In addition, Followers with extraversion trait described their leader as having Api (fire) style of leadership. Lastly, follower with agreeableness trait described their leader as having bumi (earth) style of leadership. This research ultimately identified that groups of participants with the same personality share the same perception of their leader. These findings suggest higher education policies to cluster follower personality types as an effort to improve leadership effectiveness in order to improve teamwork performance.
\end{abstract}

Keywords: followers ' personality; Indigenous leadership, astabrata leadership

\section{INTRODUCTION}

Leader and follower relationship in Higher education are quite complicated. It happens since every follower in Higher Education is essentially a leader at another level. The followers are also lecturers who lead their classes as well as colleagues in their own teams (Billot et al., 2013). This causes the follower in Higher Education is not purely a follower but also has a full control of their work project. Follower's perception of this type is clearly different from the follower in other institutions. They regard their leader as a part of colleagues and not purely in a relationship as a leader and a follower. The harmony of this relationship will determine their perception of the leader. Should these followers have a harmonious relationship in both working and interpersonal relationships, they are more likely to perceive their leader more positively. 
Leadership behavior and attitude influence followership. As for the example, leaders can encourage their followers through their behavior. (Hetland, Sandal, \& Johnsen, 2008). Thus, leadership style becomes an important element in improving follower performance. Nevertheless, leadership styles are supposed to be adjusted to the working institution, condition, team or even personnel. (Amanchukwu, Stanley, \& Ololube, 2015). If the follower views the leader's style fits the organization's condition, situation and group dynamics in the institution, the followers are expected to be able to execute their tasks and responsibilities as best as they can to meet the organization's expectations.

Lord, De Vader, \& Alliger (1986) introduced leadership perception theories. Then, Gerstner andDay (1994) studied it further by trying to find the association of positive leaders and motivated subordinates. This study showed that effective leadership and followers' opinion are related. The follower accepts them by making positive comparisons based on the existing prototypes within their subconscious (Shaw, 1990).

However, further research developed rapidly by discussing the attributes of the followers who determine their evaluation of the leader. The attributes studied were age and culture of the follower (Chong \& Wolf, 2010), gender (Hau \& Chow, 2005; Linimon, Barron, \& Falbo, 1984) and followers' personality (Felfe \& Schyns, 2006; Hetland, Sandal, \& Johnsen, 2008). The above researches show that age, gender, and personality determine their differences in perceiving the leader, whereas culture is not likely to show significant differences. Meanwhile, the research that discusses the relationship between personality (by using big five personality inventory) and perceived leadership style focuses on transformational, transactional and also passive-avoidance leadership types.

Leadership type in Indonesia is quite different from western leadership models. Studies around the world discuss much transformational leadership, transactional leadership, and passive-avoidance leadership, whereas, Indonesia acknowledges its own indigenous leadership model. However, the western leadership model is regarded as not enough in describing the leadership model in Indonesia comprehensively. It emerges due to the different values and beliefs in the organization. In order to deal with the participants' values and beliefs, a design must be clearly organized (Poulet, 1997). Besides, as contextual awareness is less noticed, it may result in the ineffective design of western leadership model concerning on the leader-follower relationship (Crosbie, 2005).

Leadership models in Indonesia grow on the culture that follows collectivism. Collectivism is an idea where society has the power to penalize someone breaking the rule. Besides, spreading rumor is common. Social control is retained through emotional intimacy, social encouragement, myths, and a believable principle that hold the in-group's norms (Triandis et al., 1988). These characteristics also color the style of leadership in Indonesian society, both at the company and at the Higher Educational Institution.

One of the indigenous leadership styles that still exists in Indonesia is astabrata leadership. The model of Astabrata leadership shows the distinctive characteristic of 
Indonesian culture because it focuses on the categorization of leadership in the power of the gods embodied in the elements of nature. Astabrata is stated in an old literature called Javanese Ramayana which teaches royal behavior. Asta means eight, so the title basically means the eight praise-worthy Hinduism gods captured in the manuscript (Molen \& Ding, 2018). That principle was taught in Indonesia by using the local culture which was expressed in art and Wayang puppet show (As'ad, Anggoro, \& Virdanianty, 2011). It makes that principle is understood by most people both by the layman and the controller.

The word Astabrata is originally derived from the book Manawa Dharma Sastra (book of Hindu law) written in Sanskrit. It is mentioned in this book that a king should act based on the eight godly attributes (Manu, Sudharta \& Pudja, 1995). The asta brata properties are explained as follows: (1) Surya (sun) is able to alter something slowly. (2) Wayu (wind) is directly involved in supervising the followers. (3) Candra (moon) is a cheerful/happy individual that please the followers. (4) Agni (fire) is passionate and brave to expel evil, (5) Prithiwi (earth) is fair and just in treating the followers (6) Indra (storm/rain) is giving an equitable advantage. (7) Waruna (sea) is respected and assertive in punishing the culpable followers. (8) Yama (restraint) is able to manage the followers (Manu, Sudharta \& Pudja, 1995).

As a matter of fact, the study of AstaBrata as indigenous leadership style has been linked to performance which has been implemented in Indonesia (Dharmanegara, Sudarma, Noermijati, \& Solimun, 2013; Sapta, Supartha, Riana, \& Subudi, 2016; Selvarajah, Meyer, Roostika, \& Sukunesan, 2016), however, its implementation in higher education has not been widely studied. One study of this leadership has been done by connecting it to the organizational wellness (Setiyowati, 2015), but has not yet profoundly discussed the dynamics of follower-leader in higher education.

There have been flourished researches studied on the relationship between follower personality (in this case using Big Five Personality Inventory measurement) and perceived leadership style. However, virtually no specific research on perceived leadership style in Indonesian indigenous leadership style version conducted.

The relationship between personality and cultural differences observed shows the personality differences between western and non-western countries. For instance, conventional and dominant families are found in non-western societies, whereas western societies are known with its equality and rights taught (Kajonius, 2017).

There are some indigenous leadership styles in non-western countries which are frequently associated with collectivism culture context, namely: (1) Paternalistic Leadership, which are authoritarianism, benevolence and moral character (Cheng, Chou, Wu, Huang, \& Farh, 2004) and a devotion to the well-mannered and high standard of exemplary character shown by a person (Weber, 1968). (2) Charismatic leadership. Bass (1990) stated that in a collectivist culture, people are mainly affected by charismatic leadership. (3) Supportive leadership. Similar to charismatic leadership, people in collectivist culture appreciate supportive leadership more than the individualistic culture (Wendt, Euwema, \& Zhytnyk, 2004). Supportive leadership means a leader who pays attention and concerns on the subordinate's needs (Rafferty \& Griffin, 2004). (4) Directive leadership style (with the use of detail tasks, 
procedures and dependency of lawful and forceful effect) is more suitable with high power distance culture, collectivism and indefinite avoidance culture (Sweeney \& McFarlin, 2015). Directive leadership defines that any decision making must be focused on the leader (Fiedler, 1995; Sagie, 1997) and the behavior control from leader to the followers is very dominant (Cruz, Henningsen \& Smith, 1999). However, the combination of both directive and supportive leadership behaviors is widely used around the world, especially in non-western cultures (Dickson et al., 2003). (4) Ethical leadership. Based on the research in working adults, it was obtained that ethical leadership has a positive impact to reliance level. This ethical leadership also defines the leader as a well-mannered person who acts according to the norm and does the leadership responsibility. These leaders are usually perceived as honest, caring and principled in making fair decisions (Shelton, 2012).

In the context of this Follower study, we underlined three things that need to be focused, namely (1) perceived leadership style which can be influenced by followers' personality, (2) follower views leader through the attitudes and behaviors shown by the leadership style applied, (3) leadership style cannot be separated from the cultural elements carried out in a region. It happens since cultural values affect one's perception toward a relationship. Furthermore, trust and allegiance are demanded by the follower (Hofstede, 1984). Thus, it would make the leader set particular hope of follower's critical thinking and action (Can \& Aktaş, 2012).

Based on those conceptual arguments and empirical evidence mentioned above, we draw a hypothesis that follower personality is related with perceived leadership style, which can be seen from the follower's perception and interaction with the leader whose leadership style is bound by the culture of the local community, all mirrored in their descriptions. Specifically, perceived astabrata leadership style will form groups according to their personality type. We would discuss whether certain types of personality trends will relate to the leadership style's perceptions.

\section{METHODOLOGY}

\section{Sample}

The data used in this research of the relationship between follower personality and perceived AstaBrata leadership style were collected from lecturers on higher education institutions in East Java.

Table 1: Participants' criteria

\begin{tabular}{lll}
\hline No & Criteria & Reason \\
\hline 1. & Civil servant status & Civil servants are vowed to have a commitment in \\
doing their job to serve the Country as it is stated \\
in Government Regulation of Indonesia, number \\
\end{tabular}

2. Serving period of 10 years Civil Servant with 10 years of serving is considered or more

that the person already understands the organization culture and entitled to propose an award called as satyalancana karya perunggu as it stipulated in Government Regulation of Indonesia 
3. In East Java

\section{No. 25 of 1994.}

East Java is selected for its social characteristics that are open, expressive, articulate and honest. Asta brata is derived from Hinduism value, covering Kutai, Tarumanegara, Mataram Kuno, Kediri and Singosari. Meanwhile, the biggest three of Hinduism kingdoms spread in East Java, even one of them is located in Singosari Malang, East Java (Pusponegoro, Marwati \& Notosusanto, 1984). It makes that in terms of value and belief, the people of East Java have a deeper concept of asta brata leadership

After those criteria were fulfilled, the researcher spread BFI Inventory to 30 participants. However, in its process, only 20 participants who returned the questionnaire in time as the deadline set by the researcher. Next, the researcher followed up the 20 participants who returned the questionnaire.

The 20 participants comprised of 7 men and 13 women. These participants were from Institute of Teaching and Education Sciences in Malang (State University of Malang) and in Surabaya (State University of Surabaya). The research process was conducted on March 12, 2018 - April 5, 2018.

Table 2: Distribution of research subjects

\begin{tabular}{ccc}
\hline Gender/Research location & Malang & Surabaya \\
\hline Men & 5 & 2 \\
Women & 8 & 5 \\
\hline
\end{tabular}

\section{Procedure}

The participants completed the Big Five personality inventory whose culture and language had been adopted (Ramdhani, 2012), with the five traits of agreeableness, conscientiousness, extraversion, openness, and neuroticism. After they were classified into these personality types, they were asked to describe how they perceived their leader who is currently working with them. The interview procedure was carried out by following an Asta Brata questionnaire list modified from the operational definition of previous research on the Leadership Javanese Model (As'ad, Anggoro \& Virdanianty, 2011).

Table 3: Operational Description of Asta Brata Leadership

\begin{tabular}{|c|c|c|}
\hline No & Asta Brata & Description \\
\hline 1 & $\begin{array}{c}\text { Matahari } \\
\text { (Sun) }\end{array}$ & $\begin{array}{l}\text { Leaders have a cautious characteristic in guiding their subordinates. } \\
\text { Leaders are able to wield the subordinate energy slowly, which will } \\
\text { unknowingly guide the subordinate to run the common objective. }\end{array}$ \\
\hline
\end{tabular}




\begin{tabular}{|c|c|c|}
\hline 2 & $\begin{array}{l}\text { Angin } \\
\text { (Wind) }\end{array}$ & $\begin{array}{l}\text { Leaders have meticulous characteristic when directly observing or } \\
\text { supervising the performance of all subordinates. The leaders have to } \\
\text { be close to the subordinate without distinguishing their status. }\end{array}$ \\
\hline 3 & $\begin{array}{l}\text { Bulan } \\
\text { (Moon) }\end{array}$ & $\begin{array}{l}\text { Leaders have cheerful characteristic who are able to please the } \\
\text { subordinates. Leaders are able to provide motivation to the } \\
\text { subordinates to improve their performance. }\end{array}$ \\
\hline 4 & $\begin{array}{c}\text { Api } \\
\text { (Fire) }\end{array}$ & $\begin{array}{l}\text { Leaders have an assertive characteristic, especially when giving } \\
\text { punishment to subordinates who make mistakes. The leader must } \\
\text { have the courage to take a decision to punish and even remove the } \\
\text { guilty subordinate in the group. }\end{array}$ \\
\hline 5 & $\begin{array}{l}\text { Bumi } \\
\text { (Earth) }\end{array}$ & $\begin{array}{l}\text { Leaders have benevolent and fair characteristics towards all their } \\
\text { subordinates. Leaders are fair by rewarding accomplished } \\
\text { subordinates without discriminating their status. }\end{array}$ \\
\hline 6 & $\begin{array}{l}\text { Langit } \\
\text { (Sky) }\end{array}$ & $\begin{array}{l}\text { Leaders have the ability to provide more knowledge to their } \\
\text { subordinates. }\end{array}$ \\
\hline 7 & $\begin{array}{l}\text { Samudra } \\
\text { (Ocean) }\end{array}$ & $\begin{array}{l}\text { Leaders have open-minded characteristic and are able to } \\
\text { accommodate the aspirations of their subordinates. }\end{array}$ \\
\hline 8 & $\begin{array}{l}\text { Bintang } \\
\text { (Star) }\end{array}$ & $\begin{array}{l}\text { Leaders have the confidence in holding firm to the principle they } \\
\text { believe. The strong principle that leaders possess is the guidance for } \\
\text { subordinates in working towards the objective. }\end{array}$ \\
\hline
\end{tabular}

In addition, there are 4 questions used during the interview process, namely "How the attitudes and behaviors do my leader express " when:

1. Facing problems in the institutions that involve many parties?

2. There are major conflicts within the institution?

3. Being in a specific project or working program?

4. In viewing the work?

After the interview process completed, the researcher did the analysis stage based on the deductive thematic analysis. The deductive analysis was conducted based on the researchers' theoretical or analytic interest and might give a more complete analysis of some aspects of the data (Braun \& Clarke, 2006) as follows:

1. Taking note of all data obtained systematically

2. Deciding code used and referring to the asta brata leadership theory

On this analysis stage, the researchers conducted a coding process per participant group based on the similarity of personality type. It was conducted to simplify the distribution of leadership and participant perception concerned. The steps were carried out by matching the interview result with the theme and code of asta brata. 
Table 4: Behavioral code of astabrata

\begin{tabular}{|c|c|}
\hline Leadership styles & Code \\
\hline Matahari (Sun) & Softly controlling (M1), Guiding (M2), Supervising (M3) \\
\hline Angin (Wind) & $\begin{array}{l}\text { Being precise }(\mathrm{A} 1) \text {, Detail observing (A2), Maintaining an } \\
\text { Intimate relationship (A3) }\end{array}$ \\
\hline Bulan (Moon) & $\begin{array}{l}\text { Being cheerful (BU1), Motivating (BU2), Having delightful } \\
\text { behavior (BU3) }\end{array}$ \\
\hline Api (Fire) & $\begin{array}{l}\text { Behaving assertively (AP1), Being directive (AP2), Having } \\
\text { discipline personality (AP3) }\end{array}$ \\
\hline Bumi (Earth) & Being sensible (BM1), Treating fairly (BM2), Doing good (BM3) \\
\hline Langit (sky) & $\begin{array}{l}\text { Being professional (L1), Thinking smart (L2), Having insightful } \\
\text { understanding (L3) }\end{array}$ \\
\hline Samodra (Ocean) & $\begin{array}{l}\text { Being open-minded (S1), Responding wisely (S2), } \\
\text { Accommodating the aspirations (S3) }\end{array}$ \\
\hline Bintang (Star) & $\begin{array}{l}\text { Having high confidence (BI1), Having a strong principle (B|2), } \\
\text { Being resilience (BI3) }\end{array}$ \\
\hline
\end{tabular}

3. Decoding the codes in themes that are suitable with the participant's perception.

4. Matching the report of interview result with the agreed theme and code

5. Conducting holistic evaluation. It should be no any concrete participants' descriptions towards the attitudes and behaviors of the leader, the researcher added an interview process to clarify what the participants meant.

6. Interpreting the result and drawing the conclusion

\section{RESULT}

The distribution of 20 participants based on the personality type was dominated with neuroticism personality with 7 participants (35\%) and the least personality was agreeableness with only one participant (1\%). Whereas, the other types such as conscientiousness was four participants (20\%), openness to experience with five participants (25\%) and extraversion with three participants (15\%).

Table 5: Participants Distribution

\begin{tabular}{lcc}
\hline Types of personalities & Number of participants & Percentages \\
\hline Neuroticism & 7 & $35 \%$ \\
Openness to Experience & 5 & $25 \%$ \\
Conscientiousness & 4 & $20 \%$ \\
Extraversion & 3 & $15 \%$ \\
Agreeableness & 1 & $1 \%$ \\
\hline
\end{tabular}




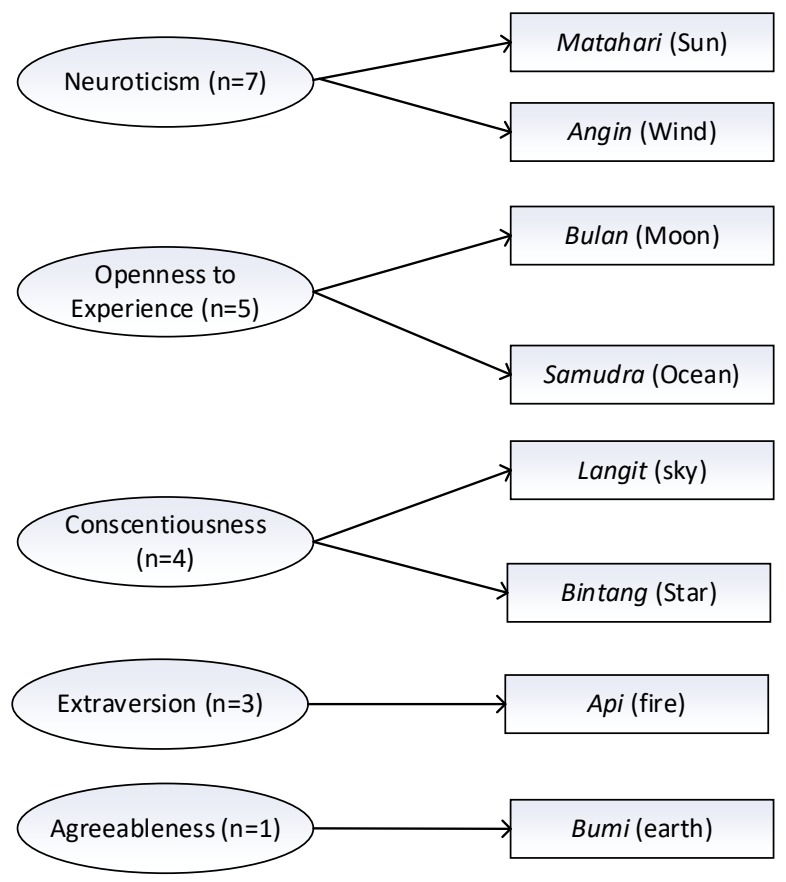

Figure 1: Relationships between followers' personality and perceived Astabrata leadership styles

Among 20 participants who were already classified in different groups of personality types, they were interviewed about their leadership perceptions. The results showed that each type of personality did not necessarily have a tendency to perceive their leader in one way. Some of them saw their leaders as having some leadership styles. Besides, the result of this research identified that not all of the indicators emerged in the transcript. If the researcher found out one or two behaviors that occurred, the subject would be classified into that category.

There were seven participants who had high neuroticism scores, consisting of five women and two men. They are all domiciled in Malang East Java, Indonesia. These seven followers tended to give a description that the leader is cautious in guiding their subordinates as well as giving encouragement in the working process such as traits depicted in sun-type leadership. In addition, thereto, the follower with this personality type described the leader as paying attention to detail and doing supervision on their subordinates. These seven participants described the existence of the process of guidance, supervision, and attention to the detail makes the subordinate become comfortable in working.

Besides, there were five participants who got high openness to experience score, whom of all were female and came from Surabaya. They described their leader as fun figures (both happy and motivating). These subordinates also explained more about their leader who is open when receiving suggestion and able to accommodate the aspirations of their subordinates. The participants portrayed the working atmosphere as harmonious because the leader makes warm interpersonal relationships. 
On the other hand, there were four participants with high conscientiousness scores comprised of two men from Malang, one man from Surabaya, and one woman from Malang. They described their leader as a smart figure and very knowledgeable. Thus, the leader becomes someone to ask questions about many things as well as appear as a role model. The subordinates chose the words of professional, smart and insightful in describing the leader.

Meanwhile, there were three participants consisting of two women from Malang and one man from Surabaya with high extraversion score to describe their leader as having decisiveness style in his/her decision making. According to them, the leader in their institutions has the ability to give explicit instructions. Participants also had the experience of receiving a loud reprimand when they made mistakes and being late in completing the task given by the leader.

One last participant, a woman from Malang gained high agreeableness score. She described her leader as a generous person. In the context of work, the follower described the leader as being helpful for the subordinates who are encountering difficulties. The leader also does not distinguish anyone who needs help. In appreciating the achievement, the leader also does not hesitate to give awards. This subordinate considered her leader a "good person" in every situation.

Table 6: Results of keyword coding on participant interviews

\begin{tabular}{|c|c|c|c|c|c|}
\hline $\begin{array}{l}\text { Personality/ } \\
\text { perceived } \\
\text { leadership }\end{array}$ & Neuroticism & Extraversion & $\begin{array}{l}\text { Openness } \\
\text { to } \\
\text { experience }\end{array}$ & $\begin{array}{c}\text { Agreeable } \\
\text { ness }\end{array}$ & $\begin{array}{c}\text { Conscient } \\
\text { iousness }\end{array}$ \\
\hline $\begin{array}{l}\text { Matahari } \\
\text { (Sun) }\end{array}$ & Guiding & -- & -- & -- & -- \\
\hline Angin (Wind) & $\begin{array}{l}\text { Supervising, } \\
\text { Attention to } \\
\text { detail }\end{array}$ & -- & -- & -- & -- \\
\hline $\begin{array}{l}\text { Bulan } \\
\text { (Moon) }\end{array}$ & -- & -- & $\begin{array}{l}\text { Fun/cheerful } \\
\text {, motivating }\end{array}$ & -- & -- \\
\hline Api (Fire) & -- & $\begin{array}{l}\text { Assertive, } \\
\text { directive, } \\
\text { discipline }\end{array}$ & -- & -- & -- \\
\hline Bumi (Earth) & -- & -- & -- & Good-man & -- \\
\hline Langit (sky) & -- & -- & -- & -- & $\begin{array}{c}\text { Professio } \\
\text { nal, } \\
\text { smart, } \\
\text { insightful }\end{array}$ \\
\hline $\begin{array}{l}\text { Samodra } \\
\text { (Ocean) }\end{array}$ & -- & -- & Open & -- & -- \\
\hline $\begin{array}{l}\text { Bintang } \\
\text { (Star) }\end{array}$ & -- & -- & -- & -- & $\begin{array}{c}\text { Self- } \\
\text { confident }\end{array}$ \\
\hline
\end{tabular}




\section{DISCUSSION}

Overall, this research showed the relationship between followers' personality with asta brata as an indigenous leadership style in Indonesian higher education. The combination of them showed that each participant had a similar personality type and perception in perceiving their leader.

Neuroticism is mainly associated with many negative emotions, such as anxious characteristic. The Five Factor Model describes neuroticism as the "tendency to experience negative effects such as fear, sadness, embarrassment, anger, guilt, and disgust" (McCrae \& Costa, 2010). Apparently, seven participants had a high score in the category of neuroticism. They gave a positive description of their leader. It is in contrast to some previous studies stating that low neuroticism score is associated with the emergence of positive perceptions of transformational leaders (Hetland, Sandal \& Johnsen, 2008).

The description provided leads to three keywords that are guiding, supervising and giving attention to the detail. It showed the nature of the sun (guiding and directing subtly) and the nature of the wind (supervising and meticulous to the detail). Participants who realized they are easily tensed yet having their leaders capable to guide, monitor and observe the details feel more secure and protected. This model of the sun and wind leadership is more a combination of directive leadership. It can be described that leaders provide direction to subordinates in their process of decision-making and all activities centered on the leader's perspective (Fiedler, 1995; Sagie, 1997). The directive leader demands duty likes to dominate the discussion, interaction, also complete personal tasks individually (Cruz, Henningsen \& Smith, 1999). Directive leadership will make subordinates more dependent, but it might be applied in particular organizational situations that demand it (Bell, Chan \& Nel, 2014).

Whereas, Openness to Experience is translated into the broad nature of insight, deep thinking, original ideas, and high-complex life experience. Employees with high openness to experience are suitable for managerial positions (Nieß \& Zacher, 2015). five participants described their leader tends to express joy in many situations. The leader also constantly motivates their subordinates who are in a state of a slump. In addition, their leader is also portrayed as an individual who is ready to accept ideas from others even from the lowest staff. The terms "motivating" and "exciting" identify the characteristics of the moon's leadership style, meanwhile the open is more related to the oceanic leadership style. This leader-follower relationship is regarded as shaping spiritual value in an organization where followers feel they get something from their activity. This spiritual value makes their action be more tied up and collaborative. They will use all of their ability and immerse themselves in the organization (Majeed, Nor, \& Mustamil, 2017).

The three combined keywords of the two Astabrata leadership styles (moon and ocean) above are relatively close to supportive leadership styles. It is defined as the leader's behavior that cares for the needs of the subordinates (Rafferty \& Griffin, 2004). Follower with high openness skill perceived their leader as a supportive leader providing a dynamic and vibrant organization atmosphere. 
In addition, conscientiousness is closely related to regularity, obedience, and sincerity in performing the task. Despite using different word choices, four participants describe that their leader is capable and skilled in his field. The participants chose the words of professional, smart, clever and insightful.

The combination of sky and star leadership style described by the participants is like the picture of paternalistic leadership and charismatic leadership at the same time. It refers to the three major elements of Paternalistic Leadership, which are authoritarianism, benevolence, and morality (Cheng, Chou, Wu, Huang, \& Farh, 2004) and a respect to the noble character and normative patterns shown by the person (Weber, 1968). Follower with obedience and willingness level to obey a rule perceives their leader as an "extraordinary" person in various aspects. In practice, the leader is perceived as parent, guidance, and source of inspiration.

Extraversion describes a person who is open, spontaneous, and passionate. There were 3 participants who had high extraversion score. Keller (1999) illustrates that high extraversion values are associated with a preference for charismatic leadership. But in this study, the participants described their leaders as having firm, directive, and discipline in holding the rules. The participants also recalled that their leader is very obedient to the procedure in the faculty and diligently giving instructions to subordinates. In some cases, their leader even takes full control of decision making, especially in an emergency situation. This pattern is more similar to an authoritarian leadership model, but the outline indicates a closer indicator of the fire nature in the Astabrata. The open subordinate illustrated more that their leader is rigid, overly controlling in the institution. It makes the subordinates feel like restrained in delivering opinion and forced to remain silent despite having many creative ideas. Based on the existing research on employee silence, the behaviors that represent authoritarian leadership will be antithetical to those who ask the followers to be brave in expressing their thoughts (Duan, Bao, Huang, \& Brinsfield, 2018).

In addition, thereto, agreeableness is very close to pro-social behavior (John et al., 2008) that is agreeing, forgiving, trusting, and mediating. This personality type often appears and is encountered in countries with collectivist cultures. However, in this study, there was only one participant who had the character. This participant was also the only one who gave a description that the leader is a "good man". At work, the leader does not hesitate to provide the necessary assistance when the subordinates are having difficulty in doing their job.

The concept of "good man" in the leadership of Astabrata is close to the earth indicator. The leader is generous, helpful and upholds humanistic moral values. This leader meets the characteristics of ethical leadership. Ethical leaders are defined to be a good person doing good deeds and performing the duty at the same time. They are described a truthful, loving and high-minded person who decide something fairly (Shelton, 2012). Follower becomes more tolerant with many differences, easy to accept discrepancies and the most prominent of this research, the respondents see everyone is good, including the leader. Besides, when leaders perform high-minded behavior, it will lead to a good culture which can reduce the turnover intention (Majeed, Jamshed \& Mustamil, 2018). 
From the overall result of this research, we could identify the relationship between follower personality and perceived leadership style of lecturers in Higher Education organizations. Yet, strangely, there was no follower regarding their leaders as having all aspects of astabrata behavior. Based on the research of Selvarajah, Meyer, Roostika, and Sukunesan (2016), it is mentioned that the leader should have all aspects of astabrata leadership style in order to achieve the best performance and quality.

These aspects are described in leadership competencies, namely: decisiveness, authority, external realities, patience, governance, trustworthiness, discerning and progressiveness. Leaders who apply astabrata leadership should demonstrate the ability to realize serenity for all people, and consistently promote compatible, equality and friendly condition without conflicts. Also, the leaders should be able to cooperate.

However, there has been not much research carried out on personality with astabrata leadership styles. The discussion of this matter was from the leaders' point of view in Indonesia, where a leader was asked to respond to whether certain variables were considered important in improving the quality of astabrata leadership. It points out a strong support between dimensions of Organizational Demands, Personal Qualities, Environmental Influences, and Managerial Behavior, also astabrata leadership to Study Leadership Excellence (Selvarajah, Meyer, Roostika, \& Sukunesan, 2016). One of the descriptions of Personal qualities is correlated with personality. This makes a research on personality and astabrata leadership styles could be developed more profoundly to answer the consistency of research results concerning the perspective of leader that has been carried out.

\section{CONCLUSION}

This study showed that personality has a relationship with its perception of the leader. Follower with a certain personality will perceive the leader in unique and different ways when compared with the follower who has another personality. Some personalities perceive their leaders to have two leadership styles at once in their daily performance. Nevertheless, groups of participants that share the same personality cluster together with each other and share the same perception of their leader.

\section{LIMITATION}

Variations of assessment of this leader can be derived from the variable follower personality, or it can also be derived from the characteristics of their leader that is not measured in this study. In addition to the variable working duration, researchers did not have control on other several variables such as gender, the age of lecturers and working relationship experience. Working relationship experience here is related to how long the follower with the perceived leader has been engaged as a teamwork. 
This study used a small number of participants. Nevertheless, the selection of research subject and sampling area in East Java, particularly in Malang and Surabaya could give a holistic description about Indonesia in general. It happens since those areas is multicultural that can represent Indonesia. Therefore, the result of this research can be used to precisely describe the leadership perception in Indonesia.

\section{REFERENCES}

Amanchukwu, R. N., Stanley, G. J., \& Ololube, N. P. (2015). A review of leadership theories, principles and styles and their relevance to educational management. Management, 5(1), 6-14. doi: 10.5923/j.mm.20150501.02

As'ad, M., Anggoro, W. J., \& Virdanianty, M. (2011). Studi Eksplorasi Konstrak Kepemimpinan Model Jawa: Asta Brata, Jurnal Psikologi Universitas Gajahmada, 38(2), 228-239.

Bass, B. (1990). From transactional to transformational leadership: Learning to share the vision. Organizational Dynamics, 18(3), 19-31. doi: 10.1016/00902616(90)90061-s

Braun, V., \& Clarke, V. (2006). Using thematic analysis in psychology. Qualitative Research In Psychology, 3(2), 77-101. doi: 10.1191/1478088706qp063oa

Bell, C., Chan, M., \& Nel, P. (2014). The Impact of Participative and Directive Leadership on Organisational Culture: An Organisational Development Perspective. Mediterranean Journal Of Social Sciences, 5(23), 70-85. doi: 10.5901/mjss.2014.v5n23p1970

Billot, J., West, D., Khong, L., Skorobohacz, C., Roxa, T., Murray, S., \& Gayle, B. (2013). Followership in higher education: academic teachers and their formal leaders. Teaching \& Learning Inquiry: The ISSOTL Journal, 1(2), 91-103. doi: 10.20343/teachlearninqu.1.2.91

Can, A., \& Aktaş, M. (2012). Cultural values and followership style preferences. Procedia - Social and Behavioral Sciences, 41, 84-91. doi:10.1016/j.sbspro.2012.04.012

Cheng, B., Chou, L., Wu, T., Huang, M., \& Farh, J. (2004). Paternalistic leadership and subordinate responses: Establishing a leadership model in Chinese organizations. Asian Journal of Social Psychology, 7(1), 89-117. doi: 10.1111/j.1467-839x.2004.00137.x

Chong, E., \& Wolf, H. (2010). Factors influencing followers' perception of organisational leaders. Leadership \& Organization Development Journal, 31(5), 402-419. doi: 10.1108/01437731011056434

Crosbie, R. (2005). Learning the soft skills of leadership. Industrial and Commercial Training, 37(1), 45-51. doi: 10.1108/00197850510576484

Cruz, Michael, G., Henningsen, David. D, \& Smith, Brian, A., (1999). The impact of directive leadership on group information sampling, decisions, and perceptions of the leader. Communication Research, 26(3), 349-369.

Dharmanegara, Ida, BA., Sudarma, M., Noermijati, \& Solimun (2013). Mediation of Tri Hita Karana organizational culture in effect of spiritual intelligence and asta brata leadership on employee performance. Interdisciplinary Journal of Contemporary Research in Business, 11(2), 475-486.

Dickson, M. W., D. N. Den Hartog, and J. K. Mitchelson. 2003. "Research on Leadership in a Cross-Cultural Context: Making Progress and Raising New Questions." The Leadership Quarterly 14 (6): 729-768. 
doi:10.1016/j.leaqua.2003.09.002.

Duan, J., Bao, C., Huang, C., \& Brinsfield, C. T. (2018). Authoritarian leadership and employee silence in China. Journal of Management and Organization, 24(1), 62-80. doi: 10.1017/jmo.2016.61

Felfe, J., \& Schyns, B. (2006). Personality and the perception of transformational leadership: The impact of extraversion, neuroticism, personal need for structure, and occupational self-efficacy. Journal of Applied Social Psychology, 36(3), 708-739. doi: 10.1111/j.0021-9029.2006.00026.x

Gerstner, C. R., \& Day, D. V. (1994). Cross-cultural comparison of leadership prototypes. Journal of Leadership Quarterly, 5(2), 121-134.doi: 10.1016/10489843(94)90024-8

Hau, I., \& Chow, S. (2006). Gender differences in perceived leadership effectiveness in Hong Kong, 20. woman in Management Review,20(4), pp.216-233. doi: 10.1108/09649420510599052

Hetland, H., Sandal, G. M., \& Johnsen, T. B. (2008). Followers' personality and leadership. Journal of Leadership and Organizational Studies, 14(4), 322-331. doi: $10.1177 / 1548051808315550$

Hofstede, G. (1984). Culture's consequences: International differences in workrelated values. Beverly Hills, California: Sage Publications

John, O. P., Naumann, L. P., \& Soto, C. J. (2008). Paradigm shift to the integrative Big Five trait taxonomy: History, measurement, and conceptual issues. In O. P. John, R. W. Robins, \& L. A. Pervin (Eds.), Handbook of personality: Theory and research (pp. 114-158). New York, NY: Guilford Press. Kajonius, P. J. (2017). Cross-cultural personality differences between East Asia and Northern Europe in IPIP-NEO. International Journal of Personality Psychology, 3(1), 1-7.

Keller, T. (1999). Images of the familiar: Individual differences and implicit leadership theories. Journal of Leadership Quarterly, 10 (4), 589-607.

Linimon, D., Barron, W. L., \& Falbo, T. (1984). Gender Differences in Perceptions of Leadership, Journal of Sex Roles, 11(12), 1075-1089.

Lord, R. G., de Vader, C. L., \& Alliger, G. M. (1986). A meta-analysis of the relation between personality traits and leadership perception: An application of validity generalization procedures. Journal for Applied Psychology, 71 (3), 402-410.

Majeed, N., Jamshed, S., \& Mustamil, N. M. (2018). Striving To Restrain Employee Turnover Intention Through Ethical Leadership and Pro-Social Rule Breaking. International Online Journal of Educational Leadership, 2(1), 39-53.

Majeed, N., Nor, M. N. M., \& Mustamil, N. M. (2017). Exploring Relationship Between Transformational Leadership and Organizational Citizenship Behaviors Through Lens of Workplace Spirituality. International Online Journal of Education Leadership, 1(1), 5-33.

Manu, Sudharta, T., \& Pudja, G. (1995). Manawa dharmasastra, Manu dharmasastra. Denpasar, Bali: Upada Sastra.

McCrae, R., \& Costa, P. (2010). NEO'T Inventories for the NEO ${ }^{\mathrm{TM}}$ Five-Factor Inventory-3 (NEO ${ }^{\text {TM }}-\mathrm{PI}-3$ ), NEO ${ }^{\text {TM }}$ Five-Factor Inventory-3 (NEO ${ }^{\text {TM }}-\mathrm{FFI}^{-3}$ ), NEO ${ }^{\text {TM }}$ Personality Inventory-Revesed (NEO PI-R ${ }^{\mathrm{TM}}$ ). Lutz, FL: PAR.

Molen, W. and Ding, C. (2018). Traces of the Ramayana and Mahabharata in Javanese and Malay Literature. Baltimore, Maryland: Project Muse.

Nieß, C., \& Zacher, H. (2015). Openness to experience as a predictor and outcome of upward job changes into managerial and professional positions. PLOS ONE, 
10(6), 1-22. doi: 10.1371/journal.pone.0131115

Pusponegoro, Marwati Juned. \& Notosusanto, Nugroho. (1984). Sejarah nasional Indonesia. Jakarta: Balai Pustaka.

Poulet, R. (1997). Designing effective development programmes. Journal of Management Development, 16(6), 428-437. Doi:10.1108/02621719710174589

Rafferty, A. E., \& Griffin, M. A. (2004). Dimensions of transformational leadership: Conceptual and empirical extensions. Journal of Leadership Quarterly, 15(3), 329-354. doi: 10.1016/j.leaqua.2004.02.009

Ramdhani, N. (2012). Adaptasi bahasa dan budaya inventori Big Five. Jurnal Psikologi, 39(2), 189-207.

Sagie, A. (1997). Lead Article Leader Direction and Employee Participation in Decision Making: Contradictory or Compatible Practices?. Applied Psychology, 46(4), 387-416. doi: 10.1080/026999497378223

Sapta, I. Ketut. S, Supartha, W.G., Riana, I.G., \& Subudi, M. (2016). The role of organizational commitment on mediating the relationship between leadership and Tri Hita Karana culture with Subak performance in Bali. European Journal of Business and Management, 8(26), 105-119.

Selvarajah, C., Meyer, D., Roostika, R., \& Sukunesan, S. (2016). Exploring managerial leadership in Javanese (Indonesia) organisations: engaging Asta Brata, the eight principles of Javanese statesmanship. Asia Pacific Business Review, 23(3), 373395. doi: 10.1080/13602381.2016.1213494

Setiyowati, N. (2015). Asta Brata: Pemetaan Kompetensi Kepemimpinan Jawa Untuk Meningkatkan Organizational Wellness Pada Institusi Pendidikan Di Jawa Timur. In H. Ek. Erawan (Ed.), conference proceeding of Embracing A New Way of Life : Promoting Positive Psychology for better a mental health (pp. 173183). Surabaya: Indonesia

Shaw, J. B. (1990). A cognitive categorization model for the study of intercultural management. Academy of Management Review, 15(4), 626-645.

Shelton, P. (2012). Nice guys (and gals) finish first: ethical leadership and organizational trust, satisfaction, and effectiveness. International Leadership Journal, 3-19. Retrieved from http://digitalcommons.georgefox.edu/gfsb

Sweeney, P., \& McFarlin, D. (2015). International Management: Strategic Opportunities and Cultural Challenges (5th ed., p. 600). Third Avenue, New York: Routledge.

Triandis, H. C., Bomtempo, R., Villareal, M. J., Asai, M., \& Lucca, N. (1988). Individualism and Collectivism: Cross-Cultural Perspectives on Self-Ingroup Relationship. Journal of Personality and Social Psychology, 54(2), 323-338. Doi: 10.1037/0022-3514.54.2.323

Wendt, H., Euwema, M. C., \& Zhytnyk, O. (2004). Leadership styles and team cohesiveness across cultures leadership styles and team cohesiveness across cultures. Leadership, 1-27. https://doi.org/10.2139/ssrn.610704

Weber, M. (1968). On charisma and institution building. Chicago: University of Chicago Press. 